\title{
Pengaruh Nilai Tukar terhadap Harga Saham Sektor Consumer Goods Industry yang Terdaftar di Bursa Efek Indonesia (BEI) pada Masa Pandemi Covid-19
}

\author{
Asti Mustika Aeni* \\ Bandung, Indonesia. \\ *astimustikaaeni@gmail.com
}

Prodi Akuntansi, Fakultas Ekonomi dan Bisnis, Universitas Islam

\begin{abstract}
This study aims to examine the effect of the exchange rate on stock prices in Indonesia the time of the Covid-19 pandemic. The population in this study is the consumer goods industry sector companies listed on the Indonesia Stock Exchange. This research period is 6 months namely from February 2020 to July 2020. Data collection is based on The world and Indonesia's economic conditions are weakening due to the Covid-19 pandemic and based on the phenomenon that the consumer goods industry business suffers losses in the midst of the Covid-19 pandemic. This study uses linear regression analysis with SPSS 23. The results show that the exchange rate has no effect to the stock price of companies engaged in the consumer goods industry sector which listed on the Indonesia Stock Exchange
\end{abstract}

Keywords: Consumer Good Industry, Exchange Rate, Stock Price

Abstrak. Penelitian ini bertujuan untuk menguji pengaruh nilai tukar terhadap harga saham di masa pandemi Covid-19. Populasi dalam penelitian ini adalah perusahaan sektor consumer goods industry yang terdaftar di Bursa Efek Indonesia. Periode penelitian ini selama 6 bulan yaitu dari febuari 2020 sampai dengan juli 2020. Pengambilan data didasarkan kondisi ekonomi dunia dan Indonesia yang sedang melemah akibat pandemi Covid-19 dan berdasarkan fenomena bahwa bisnis consumer goods industry mengalami kerugian tengah pandemi Covid-19. Penelitian ini menggunakan analisis regresi linear dengan SPSS 23. Hasil penelitian menunjukkan bahwa nilai tukar tidak berpengaruh terhadap harga saham perusahaan yang bergerak di sektor consumer goods industry yang terdaftar di Bursa Efek Indonesia.

Kata Kunci: Consumer Good Industry, Nilai Tukar, Harga Saham 


\section{A. Pendahuluan}

Ekonomi global mengalami krisis akibat pandemi Covid-19, indeks bursa saham rontok. Nilai tukar rupiah terhadap dollar ikut melemah hal ini diakibatkan banyaknya investor asing meninggalkan pasar keuangan Indonesia, harga pasar sahampun anjlok, mempengaruhi perekonomian dalam negeri. Nilai tukar sebagai salah satu variabel ekonomi makro mengalami dampak yang sangat besar. Adanya krisis tersebut memberikan dampak melemahnya nilai tukar rupiah.

Nilai Tukar Rupiah atas Dolar AS adalah jumlah mata uang Rupiah yang disepakati sama dengan satu unit mata uang asing yaitu satu Dolar.

Pandemi Covid-19 ini sangat mempengaruhi kinerja di berbagai sektor salah satunya pasar modal Indonesia. Sebab, sepanjang tahun 2020 ini Indeks Harga Saham Gabungan (IHSG) mengalami penurunan sebesar minus $18,3 \%$, yang merupakan level yang tidak pernah terjadi selama hampir empat tahun terakhir. Pada 13 Maret, perdagangan saham dihentikan untuk pertama kalinya sejak 2008 karena pandemi Covid-19. Sepanjang tahun ini IHSG mencapai level terendah yang terjadi pada 24 Maret 2020 yakni di level 3.937 atau turun minus 37,5\% dibanding penutupan perdagangan tahun 2019 .

Economic growth is the increase in the inflation-adjusted market value of the goods and services produced by an economy over time. It is conventionally measured as the percent rate of increase in real gross domestic product, or real GDP (Sri Fadilah dan Rini Lestari, 2020).

Berdasarkan uraian di atas, maka peneliti tertarik untuk mengangkat permasalahan tersebut untuk dilakukanya penelitian dengan judul "Pengaruh nilai tukar terhadap harga saham sektor consumer goods industry yang terdaftar di bursa efek indonesia (BEI) pada masa pandemi covid-19".

Selanjutnya, tujuan dalam penelitian ini adalah untuk mengetahui pengaruh nilai tukar terhadap harga saham sektor consumer goods industry yang terdaftar di bursa efek indonesia (BEI) pada masa pandemi covid-19.

\section{B. Metodologi Penelitian}

Metode penelitian yang digunakan oleh peneliti adalah metode penelitian deskriptif dengan pendekatan kuantitatif, dengan menggunakan metode ini penulis bermaksud untuk mengetahui pengaruh nilai tukar terhadap harga saham.

Sumber data yang digunakan oleh peneliti adalah data sekunder yang diperoleh dari laporan keuangan pada perusahaan sektor consumer goods industry yang terdaftar di Bursa Efek Indonesia, yang terdapat pada situs resmi perusahaan yaitu www.idx.co.id. Selain itu, peneliti pula memperoleh data mengenai perubahan Kurs pada website resmi BI yakni www.bi.go,id.

Jenis data yang digunakan oleh penulis dalam penelitian ini adalah data sekunder, maka teknik pengumpulan data yang akan dilakukan dalam penelitian ini adalah teknik studi dokumentasi. Dokumen yang digunakan adalah laporan keuangan.

Teknik analisis data penelitian ini dalam pengumpulan \& pengolahan data numerik adalah dengan metode kuantitatif deskriptif. Karena metode ini merupakan metode penelitian yang bertujuan untuk mengetahui hubungan antar variabel.

Target populasi yang menjadi objek pada penelitian ini adalah 61 perusahaan sektor consumer goods industry yang terdaftar di Bursa Efek Indonesia.

Teknik sampling yang dilakukan dalam penelitian ini adalah nonprobability sampling dengan teknik purposive sampling. Ada 25 perusahaan yang memenuhi kriteria dalam pengambilan sampel.

Rancangan Pengujian Hipotesis Analisis regresi sederhana:

1. Uji F

2. Uji t

3. Pengujian koefesien determinasi (R-Square) 


\section{Hasil Penelitian dan Pembahasan}

Nilai tukar pada penelitian ini menggunakan data yang di keluarkan oleh Bank Indonesia yang telah di publish melalui situs resminya www.bi.go.id. Nilai tukar mata uang rupiah terhadap dollar Amerika pada tahun 2020 tidak stabil terjadi kenaikan dan penurunan yag sangat drastis. Pada awal tahun 2020 nilai tukar stabil, dimana pada bulan januari dan februari 1 dolar Amerika masih berada dikisaran Rp. 13.500 - Rp. 14.500, namun saat memasuki bulan maret terjadi lonjakan yang sangat dratis 1 dollar Amerika berada dikisaran Rp. 16.500 dikarenakan dunia mengalami krisis ekonomi global adanya dampak dari pandemi covid-19, pada bulan april terjadi penurunan yakni dikisaran Rp. 15.500 , selanjutnya nilai tukar rupiah kembali stabil dikisaran Rp. 14.500 - Rp. 15.000.

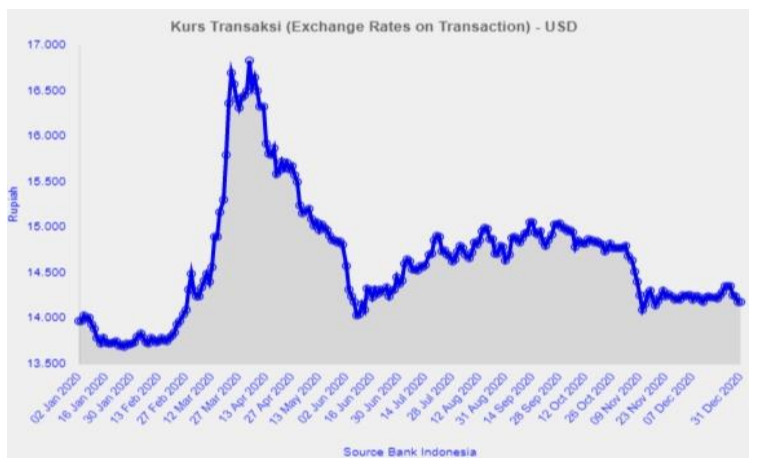

Gambar 1. Kurs Transaksi (Exchange Rates on Transaction)-USD

Nilai tersebut menunjukan bahwa nilai tukar mengalami kenaikan dan penurunan setiap bulannya, karena dipengaruhi oleh berbagai faktor seperti depresiasi dan apresiasi dari mata uang rupiah tehadap dolar AS penyebab utamanya karena pandemi virus covid-19 yang menghambat seluruh aktivitas ekonomi, nilai tukar rupiah terhadap dollar melemah hal ini diakibatkan banyaknya investor asing meninggalkan pasar keuangan Indonesia, sehingga mempengaruhi perekonomian dalam negri dan berdampak buruk bagi sebagian besar perusahaan.

Hasil pengujian pada variabel nilai tukar terbukti tidak berpengaruh signifikan terhadap harga saham sector consumer good indusrty. Adanya penurunan nilai tukar dollar terhadap rupiah menunjukkan semakin membaiknya keadaan perekonomian di Indonesia, sebaliknya dengan naiknya nilai tukar dollar menunjukkan makin lemahnya mata uang rupiah

Hasil penelitian ini menyatakan bahwa secara simultan nilai $\mathrm{F}$ sebesar 0,076 dengan Sig. 0,783. Karena nilai Sig. $\geq 0,05$, maka Ho diterima, nilai tukar tidak berpengaruh secara signifikan terhadap harga saham sektor consumer good industry. Selain hasil uji simultan, terdapat pula hasil uji koefisien determinasi $\left(\mathrm{R}^{2}\right)$. Pada hasil uji koefisien determinasi menunjukan bahwa besarnya pengaruh nilai tukar terhadap harga saham adalah sebesar $1 \%$ dan sisanya sebesar $99 \%$ dipengaruhi oleh variabel lain diluar penelitian ini

Hasil uji menunjukan harga saham berbeda-beda setiap bulannya, pada bulan febuari rata-ratanya 1279.38 bulan maret terjadi penurunan rata-ratanya 1204.22 bulan april terjadi kenaikan kembali rata-ratanya 1270.44 bulan mei kembali menurun drastis rata-ratanya 1191.36 bulan juni terjadi kenaikan kembali rata-ratanya 1267.48 bulan juli semakin naik rata-ratanya 1335.52. Nilai tersebut menunjukan bahwa tidak stabil terjadi naik turun pada harga saham, karena dipengaruh oleh berbagai faktor seperti fenomena deflasi, fluktuasi kurs rupiah terhadap mata uang asing, faktor panik karena berita-berita sehingga memicu investor untuk melepas (menjual) sahamnya yang menyebabkan tekanan jual sehingga harga saham menurun. Oleh karena itu sebelum menanamkan modal pada suatu perusahaan, seorang investor harus memperhatikan keadaan ekonomi makro seperti variabel nilai tukar dalam penelitian ini.

Dapat disimpulkan bahwa nilai tukar tidak berpengaruh terhadap harga saham sektor consumer good industry dari bulan febuari-juli. Banyak faktor lain yang mempengaruhi kenaikan dan penurunan harga saham bukan hanya nilai tukar saja. Penelitian ini sesuai dengan teori sinyal yang membahas naik turunnya harga pasar dan memberi asimetris informasi pasar 
yang sama kepada para investor dengan manajer perusahaan tentang prospek perusahaan, dan teori random walk yang membahas tentang perkiraan harga saham esok hari dapat dilakukan pada hari ini berdasarkan informasi hari ini, tetapi tidak ada jaminan mengenai kebenarannya. Adapun kelemahan dalam penelitian ini yaitu hanya satu variabel independen, jumlah sampel, dan periode pengamatan

\section{Kesimpulan}

Penelitian ini menganalisis tentang pengaruh nilai tukar variabel independen terhadap harga saham sebagai variabel dependen. Penelitian ini dilakukan pada perusahaan yang bergerak di sektor consumer good industry yang terdaftar di bursa efek indonesia (BEI) periode febuari-juli 2020.

Banyak faktor yang mempengaruhi harga saham suatu perusahaan, salah satu faktor makro ekonomi dalam hal ini nilai tukar tidak memiliki pengaruh terhadap harga saham pada sektor consumer good industry yang terdaftar di Bursa Efek Indonesia. Hasil tersebut menunjukkan persamaan dengan beberapa penelitian yang dilakukan di negara emergering market seperti Filiphina, Srilangka india, Brazil, nilai tukar tidak memiliki pengaruh terhadap harga saham.

\section{Acknowledge}

Peneliti mengucapakan terima kasih kepada seluruh pihak yang telah mendukung dan membantu dalam memberikan data maupun informasi untuk tujuan penelitian ini.

\section{Daftar Pustaka}

[1] Fadilah, Sri; Lestari, Rini; Sahdan, Mohd Hadafi; Ahmad Zamil Abdul Khalid. The Impact of Renewable Energy Consumption on the Economic Growth of the ASEAN Countries. International Journal of Energy Economics and Policy; Mersin Vol. 10, Iss. 6, (2020): 602608.Alma, Buchari. 2006. Manajemen Pemasaran dan Pemasaran Jasa. Bandung: Alvabeta.

[2] Halim, Abdul. 2014. "Teori Ekonomi Makro.” In Ekonomi Makro,

[3] Kartikaningsih, Dewi. 2020. "Pengaruh Nilai Tukar Terhadap Harga Saham Perusahaan Sektor Food and Beverage Di Masa Pandemi Covid-19."

[4] P Riyandini, E Sukarmanto, S Fadilah - 2016. " Pengaruh Intellectual Capital terhadap Nilai Perusahaan yang Diintervensi Oleh Kinerja Keuangan pada Perusahaan yang Listing di Bursa Efek Indonesia (BEI)(Studi Empiris pada Sub Sektor Perbankan Periode Tahun 20112014)

[5] Risfa Hani, Nurhayati, Sri Fadilah - 2016 "Pengaruh Voluntary Disclosure, Manajemen Laba Terhadap Cost Of Equity Capital Dengan Asimetri Informasi Sebagai Intervening Variabel pada Perusahaan Manufaktur Sub Sektor Farmasi yang Terdaftar di Bursa Efek Indonesia Periode 2012-2016)

[6] RD Kusumasari, S Fadilah, E Sukarmanto - Prosiding Akuntansi, 2018."Pengaruh Pajak, Kepemilikan Asing dan Ukuran Perusahaan terhadap Transfer Pricing (Studi Empiris pada Perusahaan Manufaktur yang Terdaftar di Bursa Efek Indonesia Periode 2012-2016)

[7] Vina Yupita, S Fadilah, Helilliana - 2016. "Pengaruh Bonus Plan, Debt To Equity Ratio, dan Political Cost Terhadap Manajemen Laba (Studi Empiris pada Perusahaan Manufaktur Sektor Makanan dan Minuman yang Terdaftar di Bursa Efek Indonesia Periode 2012-2016)

[8] Warapsari, Putu Pratiwi, Made Arie Wahyuni, and Putu Eka Dianita Marvilianti Dewi. 2017. "Pengaruh Nilai Tukar, Suku Bunga Dan Inflasi Terhadap Dolar Pada Rata-Rata Harga Saham Perusahaan Food \& Beverage Yang Terdaftar Di BEI Tahun 2012-2016.” e-jurnal S1 Ak Universitas Pendidikan Ganesha Jurusan Akuntansi Program S1 8(2). 